\title{
PENGEMBANGAN ' $G$ ULL $Y$ MELALUI PENGADAAN ALAT PRODUKSI, STRATEGI PEMASARAN DAN DESAIN LABEL KEMASAN UNTUK IRT SUSU OLAHAN
}

\author{
Lestari Setyowati ${ }^{1 *}$, Sari Kamina ${ }^{1}$, Arif Sutrisno' ${ }^{1}$, Fariza Wahyu Arizal' \\ Barotun Mabaroh² \\ ${ }^{1}$ Universitas Negeri Malang, Malang, Indonesia \\ 2Universitas PGRI Wiranegara, Pasuruan, Indonesia \\ *lestari.setyowati.fs@um.ac.id
}

\begin{abstract}
Abstrak: M99 Beverage adalah salah satu industri rumah tangga (IRT) di desa Tambakyudan, Kota Pasuruan yang bergerak pada produk olahan susu, salah satunya yaitu 'Gully (Yoghurt Jelly). Di masa sulit pandemi Covid-19, M99 Beverage terpaksa vakum setelah berupaya maksimal untuk tetap beroperasi di tiga bulan awal kasus positif Covid-19. Permasalahan yang dihadapi M99 Beverage adalah terkait dengan upaya produksi, pengemasan, dan pemasaran produk. Produksi Gully tidak berjalan secara maksimal karena masih diproduksi secara manual dan tergantung pada suhu ruangan dalam pembuatan kefirnya. Masalah lainnya adalah desain kemasan produk yang belum optimal dan strategi pemasaran yang masih manual (hanya mengandalkan pemasaran dari mulut ke mulut). Tujuan pelaksanaan pengabdian ini adalah untuk meningkatkan aktivitas produksi dan penjualan M99 Beverage sebagai mitra kegiatan melalui pengadaan alat produksi, pemasaran produk, dan perbaikan desain label atau kemasan produk. Metode yang digunakan meliputi observasi, identifikasi masalah, perumusan masalah, pelaksanaa kegiatan sebagai tindakan solusi permasalahan, dan evaluasi output Hasil pengabdian menunjukkan bahwa mitra dapat berinovasi dalam penambahan varian produk yang baru yaitu es lilin, es krim dan Gully Squeeze. Setelah kegiatan ini mitra juga berhasil mendesain label yang lebih representatif dan mencerminkan branding yang baik. Mitra juga berhasil membuat media promosi produk yang berbasis platform digital antara lain facebook, twitter, dan landing page. Dengan langkah-langkah solusi yang dilakukan melalui program ini, produksi dan penjualan mitra bertambah dari 40 botol/ minggu di bulan Juni 2021, menjadi 60 botol/minggu di bulan Juli 2021. Ini menunjukkan pengabdian kepada masyarakat ini efektif dalam meningkatkan aktivitas produksi industri rumah tangga yang bergerak dalam bidang susu olahan.
\end{abstract}

Kata Kunci: susu olahan, kefir, landing page, M99 Beverage, Gully

\begin{abstract}
M99 Beverage is one of the home industries (IRT) in Tambakyudan village, Pasuruan City that produces dairy products, one of which is 'Gully' (Yoghurt Jelly). During the Covid-19 pandemic, M99 Beverage had to halt any operations after trying operating in the first three months of Covid-19. The problems faced by M99 Beverage are related to production, packaging, and product marketing efforts. Gully production was not optimal because it is still produced manually and depends on room temperature. Other problems are related to the non-optimal design of product packaging and marketing strategies, whichare still manual (only relies on word-of-mouth marketing). The purpose of this community program is to increase the production and sales activities of M99 Beverage as a partner through procurement of production equipment, product marketing, and improvement of product labels or packaging designs. The methods used include observation, problem identification, problem formulation, implementation of problem solution actions, and evaluation of the outputs. The results of this program show that the partners can innovate in adding new product variants, namely ice wax, ice cream, and Gully Squeeze. After this program, partners also succeeded in designing labels that were more representative and reflect good branding. They have also succeeded in creating product promotion media based on digital platforms, including Facebook, Twitter, and landing pages. With the solution steps carried out through this program, partners' production and sales have increased from 40 bottles/week in June 2021, to 60 bottles/week in July 2021. This shows that this program is effective in increasing household industrial production activities, which operates in the dairy sector.
\end{abstract}

Keywords: dairy product, kefir, landing page, M99 Beverage, Gully 


\section{Pendahuluan}

M99 Beverage merupakan salah satu UKM Kota Pasuruan yang memproduksi minuman berbahan dasar susu sapi menjadi yogurt kefir dengan beragam varian rasa. M99 Beverage memiliki pangsa pasar dari siswa SMP/SMA, mahasiswa, dan pegawai perkantoran di daerah kota dan kabupaten Pasuruan. Karena adanya pandemi saat ini, target (pangsa) pasar M99 Beverage tersebut harus belajar dan bekerja dari rumah dan kondisi ini berdampak pada anjloknya penjualan produk. Bahkan, menginjak bulan ketiga dari kasus pertama positif Covid19 di Indonesia, M99 Beverage memutuskan untuk vakum meski telah berupaya semaksimal mungkin untuk tetap beroperasional.

Produk unggulan dari M99 Beverage adalah minuan Yoghurt dan Kefir hasil industri rumah tangga (IRT). Yoghurt dan Kefiradalah dua produk hasil fermentasi susu. Meski memiliki manfaat yang hampir sama dengan yoghurt, kefir dan yoghurt memiliki beberapa perbedaan. Menurut Nihayah (2015), perbedaan tersebut adalah 1) jenis kultur bakteri yang digunakan untuk fermentasi berbeda antara Yoghurt dan Kefir, sehingga Kefir dapat benar-benar membersihkan saluran penvernaan di usus; dan 2) hasil akhir Kefir dapat memberi aroma yang bervariasi, tekstur kefir lebih cair dan lebih asam dari pada yoghurt, sehingga lebih cocok untuk dijadikan minuman.

M99 Beverage berlokasi di Pasuruan yang memiliki potensi bahan baku susu sapi sangat melimpah. Hal ini dibuktikan dengan adanya dua perusahaan susu terbesar yaitu Nestle dan Indolakto yang juga beroperasi di kota ini. Menurut Kamardi (2018), bahan baku susu kefir termasuk dalam kategori sumber daya alam yang dengan kondisinya yang melimpah akan dapat mendukung kelancaran proses produksi. Tentunya juga dengan bahan baku yang melimpah akan dapat menekan biaya pengadaan bahan baku. Produksi susu sapi perah di kabupaten Pasuruan mengalami peningkatan dari tahun ke tahun (Pemerintah Kabupaten Pasuruan, 2018). Hal ini membuat andil kabupaten Pasuruan dalam memenuhi stok kebutuhan susu segar di Jawa Timur menjadi sangat penting (Pemerintah Kabupaten Pasuruan, 2018)

Mitra M99 Beverage merupakan UKM yang telah memiliki izin berusaha berupa Nomor Induk Berusaha (NIB) dan Izin Usaha Mikro Kecil (IUMK) serta dinaungi oleh Asosiasi Mamin yang dibentuk oleh Dinas Perindustrian dan Perdagangan Kota Pasuruan. Soejono et al. (2020) menyatakan bahwa pemerintah dan masyarakat sudah seharusnya turut mendukung usaha yang telah mengantongi surat legalitas untuk dapat lebih berkembang. Pemerintah dan masyarakat juga hendaknya memiliki pemahaman pentingnya mengurus izin usaha dan mengenalkan One Single Submission (OSS) untuk mengurus ijin usaha secara online dikarenakan izin usaha menjadi landasan suatu usaha untuk melakukan kegiatannya secara legal.

Namun, produk M99 Beverage dikemas dalam botol yang hanya diberikan stiker sehingga nampak kurang elegan, mudah terkelupas dan kurang menambah nilai jual. Label kemasan minuman M99 juga kurang mengesankan ciri khas produk. Selain itu, botol yang digunakan pun merupakan botol kemasan yang biasa didapatkan oleh masyarakat umum karena keterbatasan untuk memesan botol khusus M99 Beverage. Menurut Purnaningrum (2018), persaingan untuk 
memperoleh dan mempertahankan konsumen merupakan tantangan besar dan harus dihadapi oleh perusahaan dalam memasarkan produk mereka.

Berdasarkan hasil analisis situasi dan wawancara pendahuluan bersama mitra, terdapat tiga masalah utama pada proses pembuatan produk M99 Beverage. Permasalahan tersebut adalah produksi, pengemasan, dan pelabelan. Masalah pertama adalah produksi yang tidak mencapai target. Hal ini dikarenakan kefir masih diolah dengan cara manual. Susu di campur dengan bibit kefir dan diletakkan di dalam botol kaca, lalu ditunggu paling cepat $1 \times 24$ jam. Dan bila kondisi suhu dan cuaca tidak mendukung, proses fermentasi bisa memakan waktu $2 \mathrm{x}$ 24 jam. Dikarenakan proses fermentasi kefir yang manual, maka produksi kefir tidak bisa banyak. Hal ini dikarenakan membuat kefir membutuhkan waktu yang lama dan sangat tergantung cuaca. Karena produksi terbatas, pemesanan produk tidak pernah bisa memenuhi apa yang diharapkan dan penjual tidak bisa memproduksi kefir maksimal. Oleh karena itu, mitra memerlukan alat yang lebih baik untuk menambah produksi, misalnya dengan menggunakan mesin fermentasi. Permasalahan kedua adalah pengemasan produk kefir M99 dengan cara yang masih sederhana, yaitu dengan menggunakan botol bentuk yang ditempeli dengan stiker kertas yang didisain dengan Ms Word biasa. Pengemasan dan pelabelan seperti ini tentu tidak menarik karena didalamnya tidak terdapat informasi mengenai kandungan gizi dan kandungan bahan dari minuman tersebut. Oleh karena itu, sebagai upaya meningkatkan volume atau jumlah penjualan suatu produk yang ditawarkan, maka suatu unit usaha harus memiliki pengemasan produk-produk kreatif dan unik. Oleh karena itu, tim pengabdian merasa perlu untuk memberikan ciri khusus di labeling merk produk melalui sablon untuk memperbaiki pengemasan produk. Permasalahan ketiga adalah pemasaran yaitu pangsa pasar yang sangat terbatas, misalnya hanya siswa/ mahasiswa dan pegawai perkantoran wilayah kota Pasuruan saja. M99 Beverage juga memiliki keterbatasan media pemasaran yakni hanya dengan aplikasi WhatsApp Facebook, dan testimoni atau informasi dari mulut ke mulut saja. Menurut Pradiani (2017), di era saat ini, digital marketing dipandang sebagai media yang paling baik sebagai sarana promosi yang paling efektif dan efisien serta mampu meningkatkan volume penjualan yang signifikan.

Tim pengabdian memilih M99 Beverage karena UKM ini sangat potensial untuk diberdayakan berdasarkan beberapa aspek. Pertama, M99 Beverage memproduksi olahan susu segar menjadi kefir. Susu kefir mirip dengan Yogurt namun melalui proses fermentasi yang berbeda (Nihayah, 2015). Dalam kandungan susu kefir, terdapat protein, lemak, dan mikroba yang baik ubtuk tubuh (Nihayah, 2015). Selanjutnya, Aryanata (2021) juga menyebutkan bahwa susu kefir mengandung vitamin A, B, C, dan K, berbagai jenis mineral (kalsium, kalium, fosfor, dan magnesium). Susu kefir memiliki lebih banyak manfaat daripada susu sapi biasa yaitu mengurangi kadar kolesterol (Nihayah, 2015), membantu detoksifikasi racun, meningkatkan kekebalan tubuh (Aryanata, 2021), memperbaiki sistem pencernaan (Suriasih, 2013), dan mengurangi resiko penyakit turunan seperti seperti obesitas, jantung koroner, hipertensi dan kanker (Suciati \& Safitri, 2021). Dengan dasar ini, maka pengabdian kepada masyarakat ini bertujuan untuk meningkatkan aktifitas produksi dan penjualan M99 Beverage melalui pengadaan alat produksi, pemasaran produk, dan perbaikan disain label/kemasan produk. 


\section{Metode}

Untuk memecahkan permasalahan mitra, metode penyelesaian masalah dibagi menjadi beberapa langkah, yaitu observasi, identifikasi masalah, merumuskan masalah, melaksanakan kegiatan/solusi permasalahan, dan mengevaluasi output.

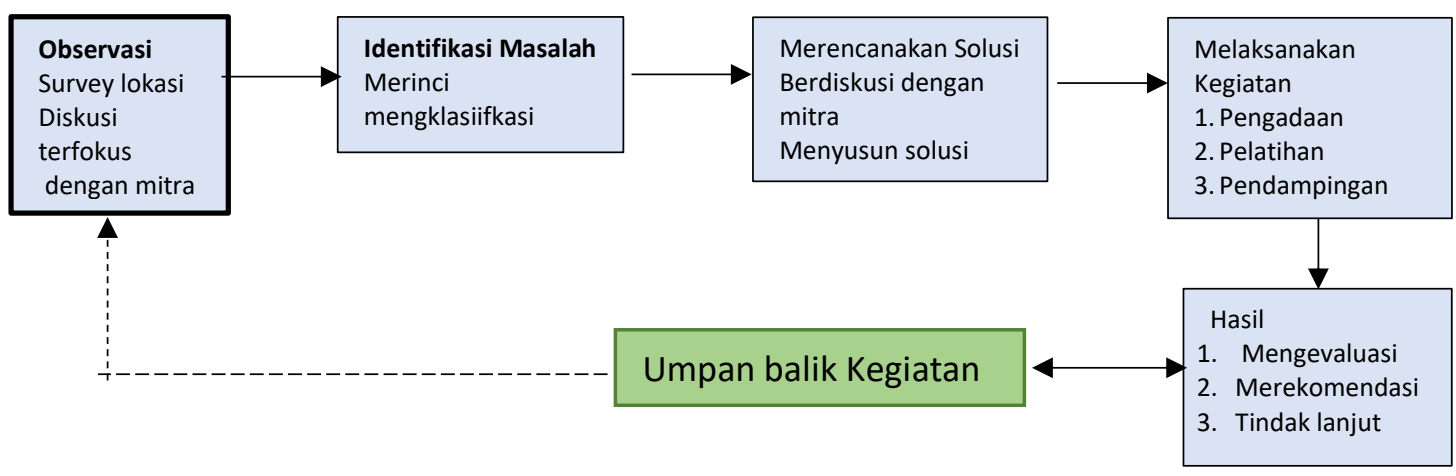

Gambar 1. Kerangka pemecahan masalah

Kegiatan diawali dengan observasi ke industri rumah tangga susu olahan milik Mitra yaitu M99 Beverage di kota Pasuruan. Observasi ini kemudian dilanjutkan dengan diskusi yang fokus pada usaha tersebut. Berdasakan hasil diskusi, tim kemudian memetakan masalah yang ada dan mengklasifikannya. Setelah itu, tim merencanakan solusi bersama mitra. Solusi yang ditawarkan adalah pengadaan mesin pembuatan yogurt, mesin aduk susu, dan redisain label kemasan untuk produkkefir, yang diberi label nama 'Gully. Seperti yang telah disebutkan diatas, 'Gully adalah kepanjangan dari Yoghurt dan jelly. Meskipun bahan minuman ini terbuat dari susukefir, owner M99 Beverage memberi nama Yoghurt dan Jell (Gully) dengan asumsi bahwa masyarakat umum lebih mengenal yoghurt daripada kefir. Setelah merencanakan, tim kemudian membagi pelaksanaan kegiatan sesuai spesifikasi bidang keahlian dan tugasnya. Pada langkah ini, kegiatan yang dilkakukan adalah pengadaan teknologi tepat guna, pelatihan dan pendampingan. Pendampingan penggunaan mesin dilaksanakan selama dua minggu. Setelah pendampingan, mitra diminta untuk mempraktekkan penggunan mesin dan merekamnya dalam bentuk video. Langkah selanjutnya adalah mengevaluasi hasil dan melaksanakan feedback.

Tim juga sering melakukan diskusi dengan mitra baik sebelum dan selama pelaksanaan pengabdian pada masyarakat ini. Fokus diskusi membicarakan mengenai variasi produk, strategi pemasaran, dan peningkatan kualitas produksi. Kegiatan pengabdian ini dinyatakan berhasil bila mitra mampu memenuhi tiga persyaratan minimal. Kriteria tersebut yaitu bila 1) mitra mampu mengoperasikan dan memanfaatkan teknologi tepat guna untuk meningkatkan produksi susu olahan, 2) mitra mampu berkreasi dengan varian rasa dan varian produk kemasankefir untuk meningkatkan produksi susu olahan, 3) mitra mampu mengoperasikan landing page yang ada.

\section{Hasil dan Pembahasan}

\section{Proses Produksi}

Untuk membantu peningkatan produksi tim mengadakan alat-alat teknologi tepat guna. Serah terima pengadaan alat teknologi tepat guna pada M99 Beverage pasuruan diserahkan 
secara bertahap. Pada tanggal 28 Mei diserahkan bantuan alat sablon botol dan pada tanggal 11 Juni 2021 diserahkan bantuan alat pembuatkefir dan pengaduk susu.

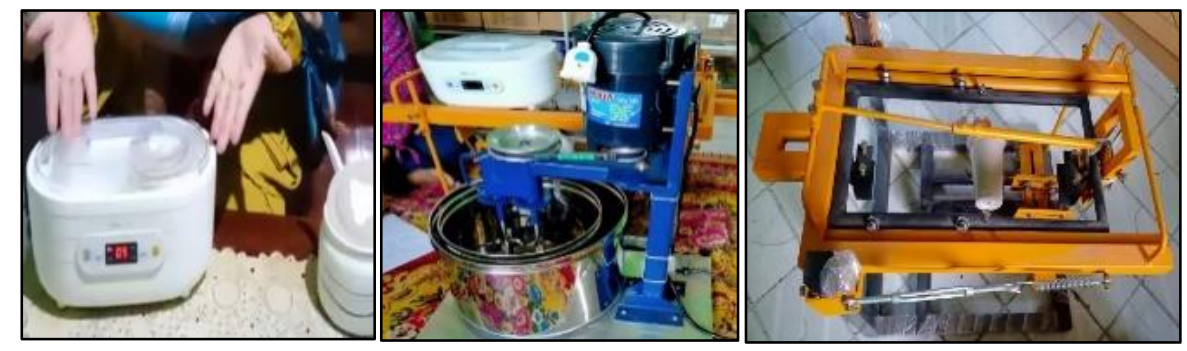

Gambar 2. Pengadaan alat pengabdian

Alat fermentasi kefir sudah dilengkapi fitur setting timer, indikator timer digital, auto power off. Satu set mesin ini terdiri dari 1 buah Mesin Fermentasi, dua buah gelas porcelain ukuran $0.5 \mathrm{~L}$ Bersama tutup vakum, dan enam buah gelas porcelain ukuran $125 \mathrm{ml}$ Bersama tutup vakumnya. Listrik yang dibutuhkan sangat rendah yaitu hanya 20 watt. Alat ini berukuran $27 \times 16 \times 15 \mathrm{~cm}$. Alat kedua yang diserahkan adalah mesin pengaduk adonan susu untuk menjadi es krim. Alat ini adalah stand mixer serbaguna kapasitas besar, dengan berat 18.000 gram. Spesifikasi alat ini adalah kapasitas : 15 liter, pengaduk : stainlees steel, daya : 125 watt, dimensi : $40 \times 45 \times 60 \mathrm{~cm}$, kecepatan : 280 rpm. alat ini berupa 1 buah mixer, 2 wadah stainless steel, 1 gelas ukur plastic 1 paket sendok takar, 1 buah spatula es krim (packing sudah termasuk palet kayu). Alat yang ketiga adalah alat sablon manual untuk botol, gelas, cup. Alat ketiga adalah mesin sablon untuk botol, gelas, plastic cup. Alat ini terdiri dari screen gelas plastic, moelding cups plastic, rangka terbuat dari besi dengan berat $17 \mathrm{~kg}$, ukuran alat adalah $55 \times 75 \times 55 \mathrm{~cm}$, rakel karet datar,tinta gelas kaca dan minyak, dan obat film screen. Untuk mengoperasikan alat ini, tim pengabdi mengundang ahli sablon untuk mengadakan pelatihan sablon.

Tim pengabdian juga menggagas bahwa M99 Beverage perlu menyajikan bungkus produk yang juga tersablon agar semakin membuat konsumen tertarik dan familiar dengan produk M99 Beverage. Sablon di kemasan botol yang digagas oleh tim pengabdian akan memasukkan unsur inovasi warna, material, dan typografi. Menurut Jannah (2016), typografi yang ditampilkan pada kemasan produk harus memuat merek perusahaan, logo, khasiat atau kegunaan, keterangan produk, alamat dan sosial media. Typografi terkait detail khasiat atau kegunaan, keterangan produk, dan sosial media belum tertulis di stiker produk. Oleh karena ini, alamat sosial media perlu ditambahkan untuk menjangkau pasar yang lebih luas dan penjualan yang meningkat.

Secara formal, pengadaan alat tersebut di serahkan pada tanggal 18 Juni 2021 di rumah mitra, di jalan TambakYudan no 42, Kebonagung kota Pasuruan. Untuk mengabadikan momen tersebut, tim pengabdian mengirim berita tersebut ke KABARPAS.COM. Kabarpas adalah koran online milik warga kota/Kabupaten Pasuruan. Berita tersebut dapat diakses di laman https://www.kabarpas.com/tim-dosen-um-beri-bantuan-alat-pengolahan-yoghurt-di-industrirumah-olahan-susu/ 


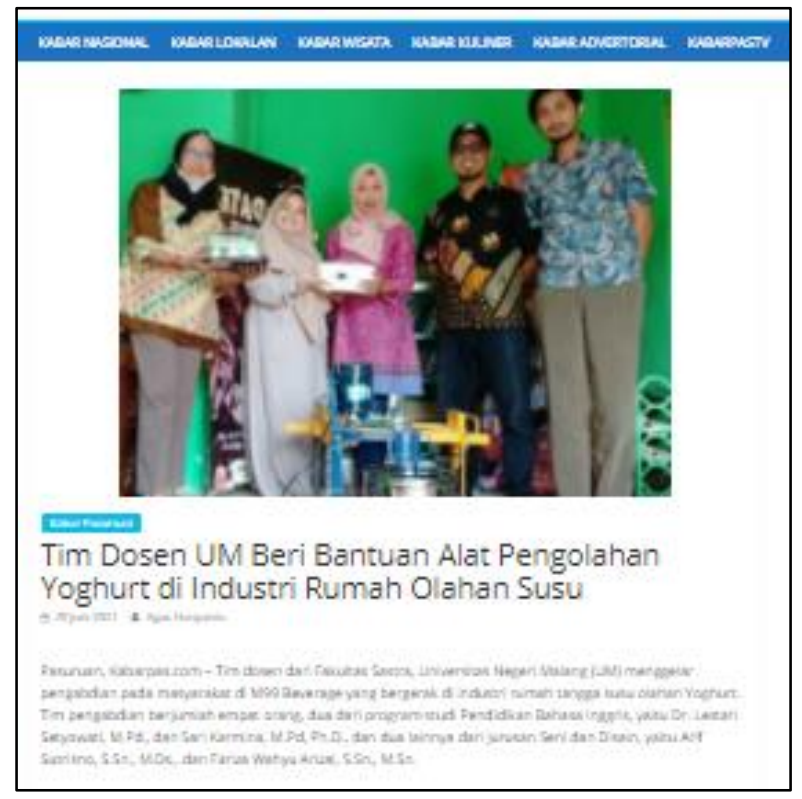

Gambar 3. Berita koran penyerahan alat bantuan produksi

\section{Pembuatan Kefir Aneka Rasa (Gully) dan Aneka Kemasan}

Gully adalah produk olahan susu jenis yoghurt yang telah diberi rasa-rasa. Pada dasarnya, minuman ini memiliki dua proses pembuatan, yaitu pengolahan susu menjadikefir, dan pencampurankefir dengan air, gula, krimmer untuk menjadi Gully. Cara pembuatan kefir secara manual adalah sebagai berikut (untuk minuman Gully $320 \mathrm{ml}$ ), bahan yang dibutuhkan adalah susu sapi segar 100-150 ml, bibit kefir 5 gr. Tahap pertama pembuatannya adalah mempasturisasi susu sapi segar bisa dengan alat atau diaduk di atas kompor dengan panas stabil. Setelah mendidih, diamkan sampai dingin sesuai suhu ruangan. Setelah itu, masukan susu yang telah dipasturisasi dalam toples kaca dan campur dengan bibitkefir. Tutup toples rapat-rapat da diamkan dalam $2 \times 24$ jam, bisa kurang atau lebih bergantung dengan suhu ruangan.

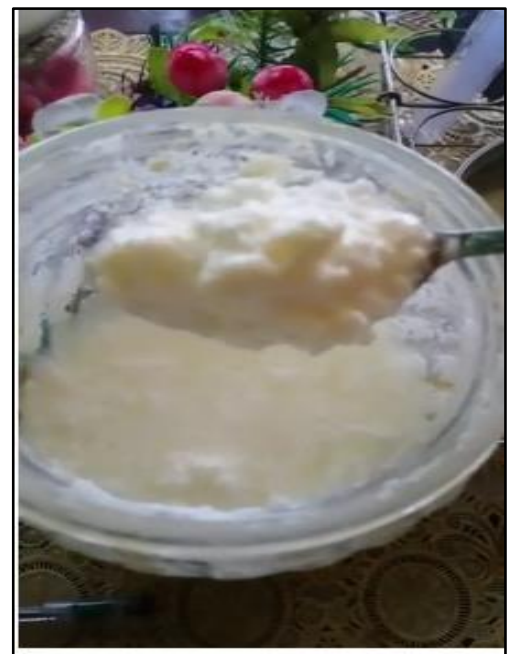

Gambar 4. Kefir yang sudah jadi dengan cara manual 
Untuk pembuatan kefir dengan menggunakan alat, cara pembuatannya otomatis dan tidak membutuhkan waktu yang lama. Biasanya waktu yang dibutuhkan adalah 10 jam, berbeda dengan pembuatan kefir manual yang membutuhkan waktu 24 jam - 2x 24 jam. Langkah yang harus dilakukan pertama adalah masukkan susu segar ke dalam gelas porcelain sebayak 300 $\mathrm{ml}$, lalu ditabahkan bibitkefir sebanyak 50-70 ml. Setelah itu diaduk sebenatr lalu ditutup rapat. Setelah itu wadah diletakkan pada mesin fermentasi dan timer di set sesuai dengan waktu yang diinginkan.

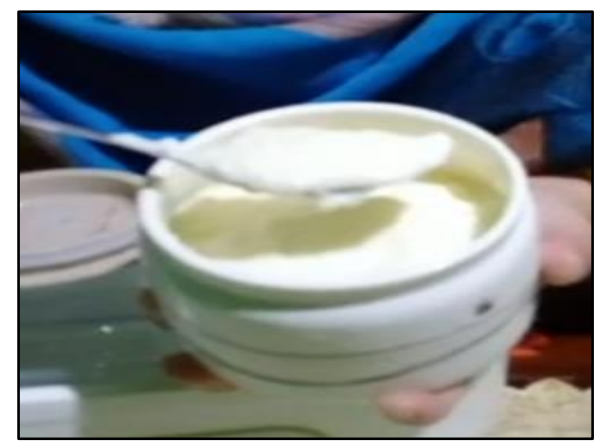

Gambar 5. Hasil kefir dengan alat Fermentasi

Kefir yang dibuat dengan mesin fermentasi memiliki tekstur yang lebih lembut. Rasakefir yang asli adalah masam. Bahan inilah yang akan menjadi dasar pembuatan Gully. Untuk membuat Gully bahan yang dibutuhkan adalah air, gula, krimmer, macam-macam rasa dankefir. Tahap pertama adalah mencampur air, gula, krimmer dan aduk merata dengan blender sekitar 1 menit. Setelah itu, masukkan susu yang telah difermentasi menjadikefir, dan aduk Kembali selama 20 detik.

Mitra saat ini juga mengembangkan varian baru dari Yoghurtkefir (Gully), yaitu dalam kemasan es lilin, Gully Squeeze yang dikemas dalam kemasan spoutpack sederhana, dan es krim. Berdasarkan analisis pasar, diketahui bahwa banyak konsumen yang menanyakan tentang es Gully. Oleh karenanya mitra berinovasi dengan mengemas Gully cair menjadi es lilin.

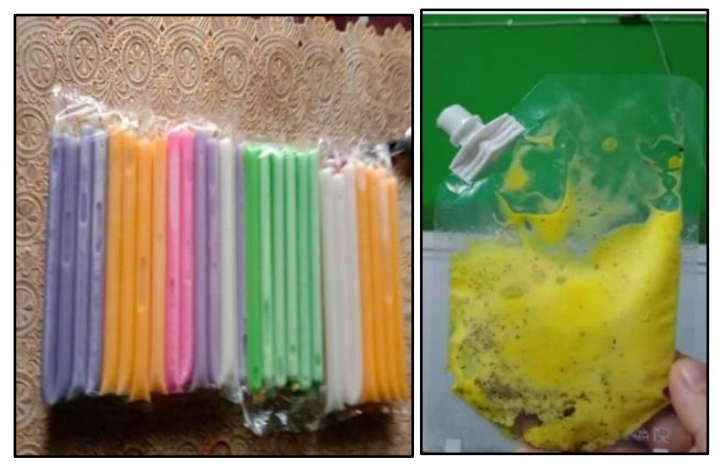

Gambar 6. Es lilin Gully dan Gully Squeeze

Es lilin Gully ini dijual perpaket, yaitu paket 10/pak, dan paket 25/pak. Selain itu, atas saran tim, mitra juga mengembangkan varian lainnya yaitu Gully squeeze. Di pasaran, beredar produk Yoghurt yang berbentuk Yoghurt squeeze. M99 berupaya berinovasi dengan membuat produk serupa, namun tidak menggunakan bibit yogurt, tapi menggunakan bibit kefir dan menggunakan rasa nanas. Rasa yang tidak dimiliki oleh pesaing bisnis lainnya. Gully squeeze 
ini dibuat dengan tanpa bahan pengawet. Karena tidak menggunakan bahan pengawet, diantaranya adalah emulsifier dan stabilizer, maka yoghurt squeeze tidak dapat bertahan lebih dari 3 hari. Lebih dari tiga hari, adonan yoghurt squeeze akan menjadi lembek dan cair. Oleh karena itu, mitra dan tim tidak bisa memasarkan produk ini, dan untuk sementara yogurt squeeze berhenti sampai sebatas inovasi. Pengembangan produk yang ketiga yaitu es krim Gully.
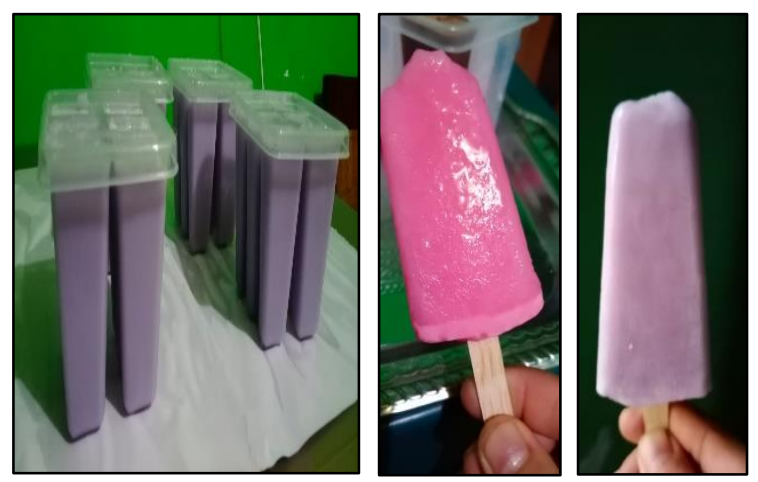

Gambar 7. Es krim Gully

Es krim Gully ini disukai oleh konsumen. Setiap potong es krim dijual dengan harga Rp. 2000 rupiah. Namun, es krim ini dibungkus dengan kemasan es krim yang dijual bebas di pasaran. Untuk menambah branding, maka es krim harus di kemas dengan kemasan yang menampilkan ciri khas Gully.

\section{Pengemasan}

Pengemasan M99 Beverage menggunakan botol aneka bentuk. Khusus untuk Yoghurt kefir (Gully), botol berbentuk seperti melon/apel. Disain kemasan berbentuk label yang ditempelkan di botol. Berdasarkan masukan dari tim pengabdi, disain label harus memuat konsistensi agar tidak membingungkan konsumen. Terlebih owner M99 beverage telah membuat pin dan logo yang berbeda dengan label kemasan tempel dengan lambing sapi dan bakground warna biru. Berdasar bekal konsistensi inilah, akhirnya tim dan mitra merancang label Gully dengan background warna senada.
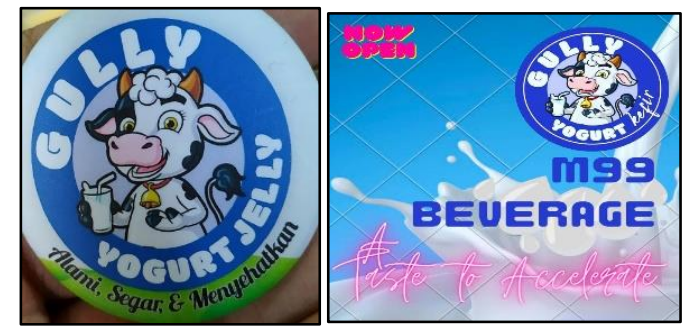

Gambar 8. Disain label Gully

M99 Beverage juga membuat varian baru dari Gully yang berupa es krim. Selama ini, bungkus es krim hanya dibungkus dengan bungkus seadanya dengan kemasan es krim yang dijual bebas. Hal ini tidak mencerminkan keunggulan produk sama sekali. Tim dan mitra kemudian berdiskusi dan menghasilkan disain label kemasan es krim dengan warna dasar biru untuk menjaga konsistensi branding. 


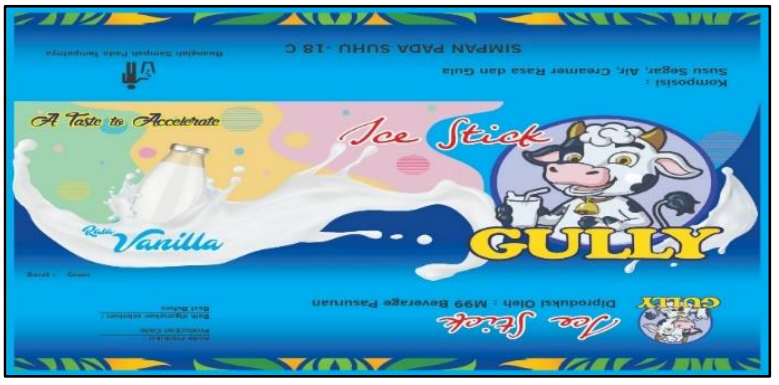

Gambar 9. Disain kemasan es krim Gully

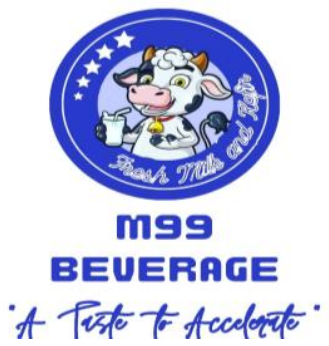

Gambar 10. Desain sablon botol

Pengemasan dibuat sebagus mungkin karena pengemasan yang baik akan menarik pembeli untuk membeli produk yang dihasilkan. Desain sablon botol tidak lah jauh dari desain dasar Gully. Berdasarkan saran dari tim pengabdian, mitra berupaya semaksimal mungkin untuk membuat desain sablon botol konsisten dari segi logo dan warna. Namun, agar hasil sablon yang maksimal, mitra harus menggunakan jasa sablon untuk membuat film terlebih dahulu, lalu menempelkan screen film tersebut ke alat sablon botol.

\section{Pemasaran}

Untuk mengatasi masalah pemasaran, tim pengabdian membekali mitra dengan promosi produk berbasis digital melalui media sosial. Selain itu, tim pengabdian akan mengarahkan mitra untuk menerapkan strategi mengelola pemasaran dan promosi digital melalui media sosial dan sistem landing page. Media sosial yang dimaksud yaitu aplikasi facebook dan instagram. Landing page adalah halaman dalam website yang didesain khusus dengan mindset marketing dan memuat informasi lebih detail dan spesifik tentang produk, service, penawaran, varian produk, promo, nomor telepon yang bisa dihubungi, media sosial yang terkait dengan produk, alamat rumah produksi, produk terlaris, dan informasi varian baru. Landing page ini bisa ditautkan secara langsung pada story ataupun feed di Facebook dan Instagram.

Menurut Indrawati, Sudiarta, \& Suardana (2017), efektivitas iklan diukur berdasarkan dampak iklan dan komunikasi dari satu iklan dengan menggunakan teknik model EPIC, yang pada akhirnya akan mempengaruhi konsumen dalam memilih suatu produk. Empat dimensi EPIC yakni Dimensi Empathy, Persuasion, Impact dan Communication. Keempat dimensi tersebut akan didapatkan dengan optimalisasi aplikasi yang paling banyak diketahui oleh calon pembeli. Berdasarkan penelitian Indrawati et al. (2017), maka tim pengabdian memilih media sosial Facebook dan Instagram sebagai media pemasaran digital bagi M99 Beverage. Sedangkan landing page digunakan untuk memudahkan calon pembeli memilih menu dan bertransaksi secara langsung dengan M99 Beverage.

Pemasaran juga dilakukan melalui landing page dimana semua produk mitra diposting di landing page tersebut. Landing page terhubung dengan WhatsApp sehingga pembeli hanya perlu menekan logo WhatsApp untukbisa terhubung dengan penjual. 


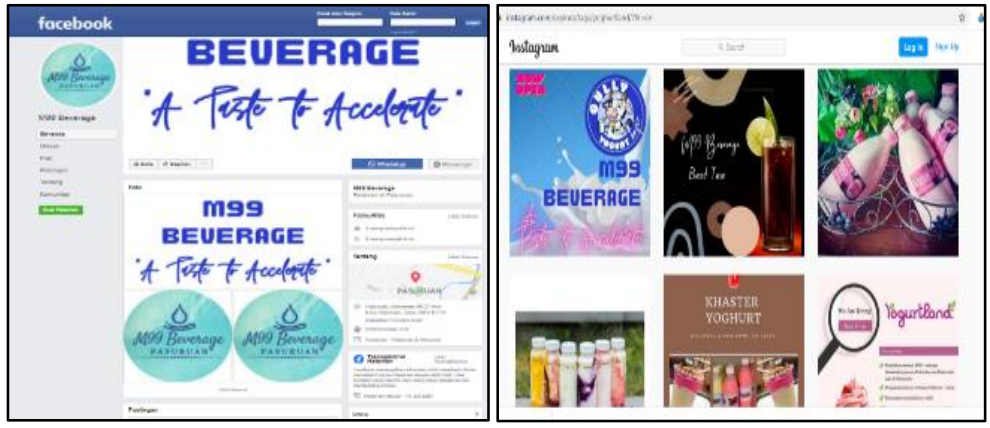

Gambar 11. Pemasaran di media sosial facebook dan Instagram
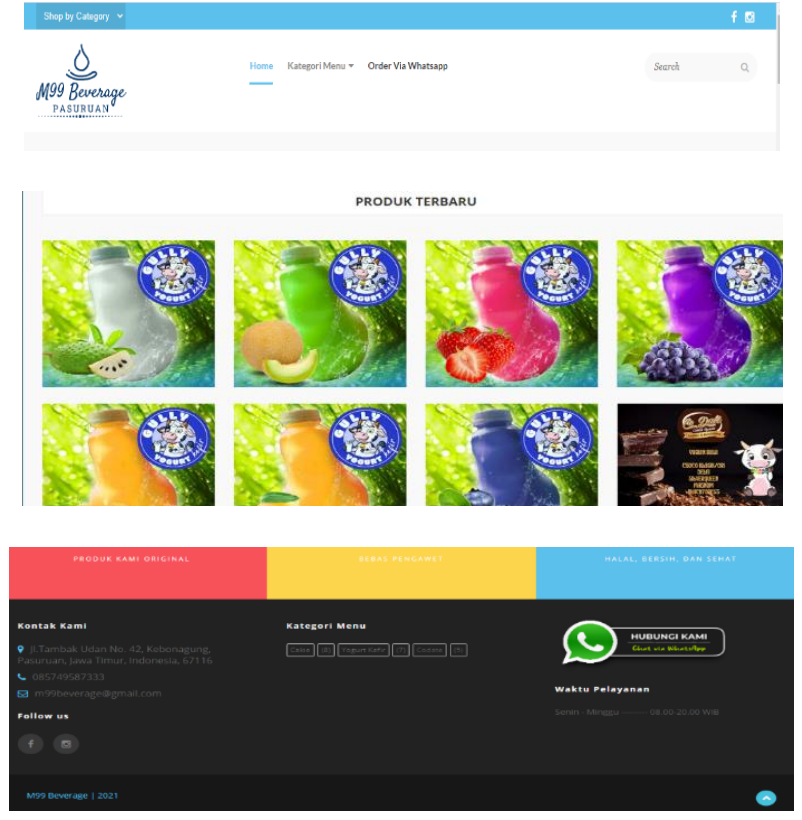

Gambar 12.Landing page M99 Beverage

Landing page M99 Beverage dapat diakses di internet melalui laman http://www.m99beverage.com/. Landing page tidak hanya berisi produk M99 Beverage yang berupa Yoghurtkefir, namun juga produk yang lainnya seperti Codate dan Cakie. Hal ini akan mengarahkan pembeli untuk dapat secara langsung berkoneksi dengan penjual dan memesan produk yang diinginkan. Landing page ini juga terhubung dengan Facebook dan Instagram M99 Beverage. Pembeli bisa memesan produk yang diinginkan dengan media sosial yang ada.

\section{Evaluasi Kegiatan}

Evaluasi merupakan pengukuran hasil dalam suatu kegiatan yang dilaksanakan. Menurut Sudarwati \& Prasetyawati (2016), evaluasi usaha akan menunjukkan rasio profitabilitas penjualan dan rasio aktivitas usaha. Evaluasi ini sangat penting karena merupakan suatu upaya untuk mengetahui sejauh mana tingkat keberhasilan pelaksanaan usaha, sehingga dapat memandu pemilik usaha untuk mengoptimalkan penggunaan dana yang dimilikinya dan memperkecil resiko kegagalan usaha. Dalam program pengabdian ini, evaluasi dilakukan dengan membandingkan hasil penjualan produk serta pemanfaatan pemasaran digital dan 
penjualan sebelumnya yang dilakukan oleh M99 Beverage. Evaluasi ini dilakukan oleh tim pengabdian bersama dengan mitra untuk mendapatkan kesimpulan hasil kegiatan yang lebih objektif.

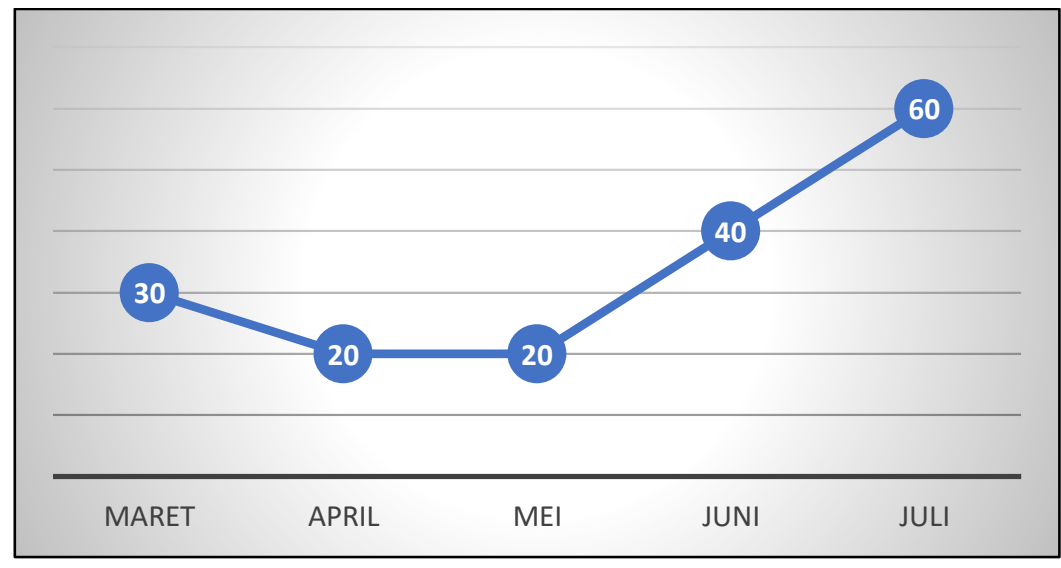

Gambar 13. Rata-rata penjualan M99 tiap bulan

Dari Gambar 13 dapat dilihat bahwa penjualan M99 Beverage mengalamai penurunan yang sangat signifikan di bulan April dan Mei. Terdapat beberapa penyebab dari penurunan ini, yaitu bulan April masuk di bulan puasa yang kebetulan juga berada di masa pandemi. Oleh karena itu, penjualan minuman tidak bisa sebaik sebelum bulan puasa. Di bulan Mei, penjualan juga stagnan karena terkendala bahan baku. Bahan baku yang berupa bibit kefir dan krim harus di datangkan dari luar kota, yang kebetulan juga mengurangi produksi karena pandemic. Bahan baku baru bisa didapatkan setelah hari raya. Oleh karena itu, dapat dilihat bahwa di bulan Juni, penjualan berangsur naik. Dan di bulan Juli, penjualan semakin baik yang mencapai 60 botol/minggu.

Penjualan yang semakin baik di bulan Juni dan Juli ini salah satunya disebabkan oleh system pemasaran yang tidak lagi dari mulut ke mulut, namun menggunakan basis digital. Pemanfaatan internet sangat membantu pengembangan bisnis. Seperti yang dikatakan oleh Amir \& Mustikawati (2019), internet telah menjadi kebutuhan dalam bisnis, baik dalam promosi maupun dalam hal penjualan produk. Lebih lanjut mereka mengatakan bahwa, penggunaan teknologi digital mempermudah promosi, transaksi dan menghemat biaya marketing.

Berdasarkan-pada semua penjualan minuman olahan susu tersebut, terdapat beberapa varian yang paling diminati oleh konsumen. Di awal produksi Gully, varian rasa yang paling digemari adalah blueberry. Varian ini bertahan selama berbulan-bulan. Varian-varian lain dari Gully leci, strawberry, sirsak, durian, melon, dan anggur. Berdasarkan analisis pasar, dapat diketahui bahwa terdapat dua pesaing pasar dari produk Gully. Pesaing pasar itu adalah produk Cimory dan Greenfield, dua perusahaan olahan susu menjadi Yoghurt yang salah satunya berada di kabupaten Pasuruan. Produk Cimory dan Greenfield memiliki semua varian rasa, kecuali nanas. Oleh karena itu, tim bersama mitra memutuskan untuk mencoba varian Gully rasa nanas. Dan hasil pasar menunjukkan bahwa sejak varian nanas diluncurkan di bulan Mei, Gully nanas menjadi favorit, mengalahkan blueberry. 


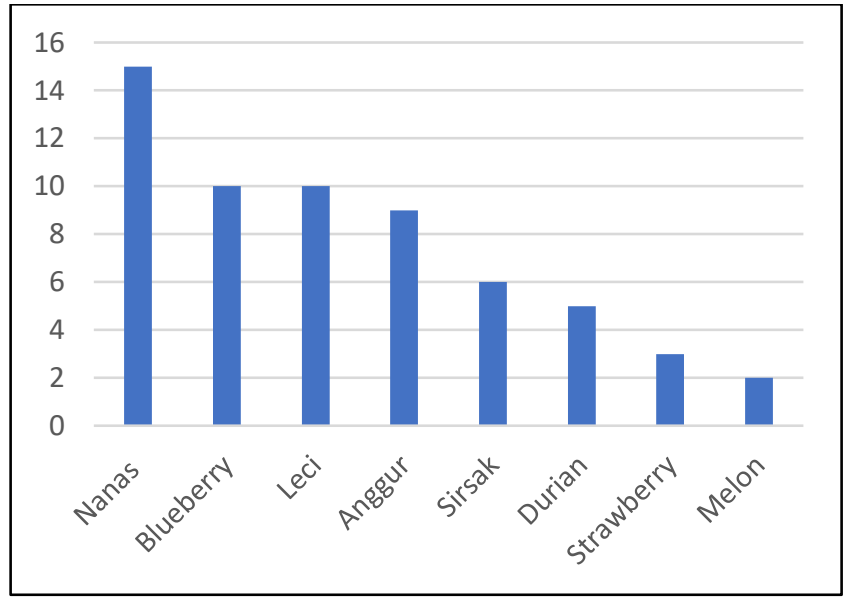

Gambar 14. Varian Rasa Pilihan Konsumen

Gambar 12 menunjukkan bahwa Gully nanas adalah varian best seller yang paling laris dan paling digemari oleh konsumen. Varian nanas memilki rasa yang lebih segar karena rasa kemasamankefir dan rasa nanas bercampur menjadi satu. Rasa manis dan kecut yang menyegarkan membuat Gully varian nanas tidak membosankan untuk dikonsumsi. Data diatas menunjukkan terdapat peningkatan penjualan Gullydi M99 Beverage. Besar kemungkinan trend ini dapat berlangsung lebih baik di bulan-bulan mendatang.

\section{Kesimpulan}

Pelaksanaan pengabdian masyarakat dalam skema kewirausahaan ini dianggap telah berjalan dengan baik. Terdapat tiga tolok ukur keberhasilan dalam pengabdian ini. Tolok ukur tersebut adalah 1) mitra dapat mengoperasikan teknologi tepat guna (mesin fermentasi, mesin pengaduk, dan sablon botol dengan baik) untuk meningkatkan produksi Gully, 2) mitra mampu melakukan inovasi varian rasa dan produk Gully, dan 3) mitra mampu memanfaatkan media sosial digital (facebook dan Instagram) dan/anding page untuk pemasaran Gully. Mitra telah mampu memenuhi ketiga tolok ukur ini dengan baik. Namun terdapat beberapa permasalahan yang masih perlu dipecahkan dalam pengabdian ini. Yang pertama adalah cetak kemasan es krim sangat mahal dan harus dalam jumlah besar. Sekali cetak bungkus es krim harus mencetak 300.000 bungkus, dan biaya yang dikeluarkan sangatlah besar, yaitu sekitar 45 juta. Permasalahan inilah yang harus diselesaikan untuk pelaksanaan pengabdian pada masyarakat di M99 Beverage pada masa mendatang.

Beberapa saran disampaikan pada mitra terkait keberlangsungan dan keragaman produk M99 di masa mendatang. Saran dan rekomendasi tim pengabdian adalah 1) M99 Beverage dimasa mendatang harus mampu menambah lebih banyak produksi dari varian produk yang sudah dipercaya oleh masyarakat dan menambah karyawan untuk membantu produksi dan pemasaran; 2) M99 Beverage bisa bekerja sama dengan perguruan tinggi yang memiliki jurusan teknologi pangan untuk mendapatkan masukan mengenai bahan pengawet yang bersahabat dan aman konsumsi. Bahan pengawet diperlukan agar produk dapat bertahan lebih lama; 3) M99 Beverage juga harus mulai memikirkan pengemasan untuk Gully Squeeze agar lebih 
menarik dan dapat bersaing secara komersial di pasar produk olahan susu, 4) mitra harus mematenkan merk dagang dan logo Gully yang dipakai pada produk ini agar tidak di klaim oleh pesaing bisnis lainnya; 5) mitra juga disarankan untuk meng-HKI kan desian label kemasan es krim dan label kemasan agar terdapat perlindungan hukum terhadap karya cipta.

\section{Ucapan Terimakasih}

Pengabdian masyarakat dalam skema program pengembangan kewirausahaan: mahasiswa dan masyarakat ini dibiayai oleh PNBP Universitas Negeri Malang untuk pendanaan Tahun 2021.

\section{Referensi}

Aryanata, I.W.R. (2021). Kefir Dan Manfaatnya Bagi Kesehatan. E-Jurnal Widya Kesehatan, 3(1), 35-38.

Amir, N.O \& Mustikawati, D. (2019) Penerapan Digital Marketing Dalam Meningkatkan Pendapatan Pedagang Bunga Di Desa Sidomulyo Kota Batu. Jurnal Ekonomi Pertanian dan Agribisnis (JEPA), 3(4), 681-688. https://doi.org/10.21776/ub.jepa.2019.003.04.3

Indrawati, AP., Sudiarta, IN., \& Suardana, IW. (2017). Efektifitas Iklan Melalui Media Sosial Facebook dan Instagram sebagai Salah Satu Strategi Pemasaran di KRISNA Oleh-Oleh Khas Bali. Jurnal Analisis Pariwisata, 17(2), 78-83.

Jannah, M. (2016). Inovasi Kemasan Produk Pada UD.SEGER WARAS Kecamatan Puger Kabupaten Jember. Repository Universitas Negeri Jember. Diakses di: https://repository.unej.ac.id/handle/123456789/76640

Kamardi, A. (2018). Analisis Faktor-Faktor yang Mempengaruhi Produksi Tahu di Kota Solok. Repositori Universitas Andalas. Diakses di http://scholar.unand.ac.id/41984/

Nihayah, I. (2015). Pengaruh Konsentrasi Starter Terhadap Kualitas Kefir Susu Sapid dan Pemanfaatannya Sebagai Penurun Kadar Kolesterol Mencit (Mus musculus). Skripsi jurusan biologi, Fakultas Sains Dan Teknologi, Universitas Islam Negeri (UIN) Maulana Malik Ibrahim Malang. http://etheses.uin-malang.ac.id/426/

Pemerintah Kabupaten Pasuruan. (2018). Sapi Perah. Diakses dari https://www.pasuruankab.go.id/potensi-167-sapi-perah.html

Pradiani, T. (2017). Pengaruh Sistem Pemasaran Digital terhadap Peningkatan Volume Penjualan Hasil Industri Rumahan. Jurnal IImiah Bisnis Dan Ekonomi Asia, 11(2), 46-53. https://doi.org/10.32812/jibeka.v11i2.45

Purnaningrum, E. (2018). Pengembangan Pemasaran Online dan Pengemasan Produk Berperan terhadap Hasil Daya Jual. Jurnal Penamas Adi Buana, 2(1) , 7-10.

Soejono, F., Sunarni, T., Bendi, R. KJ., Efila, MR., Anthony, S., \& Angeliana, W. (2020). Pendampingan Usaha: Penggunaan One Single Submission untuk Ijin Usaha. Jurnal Wikrama Parahita, 2(4), 104-108. https://doi.org/10.30656/jpmwp.v4i2.2214

Suciati, F, \& Safitri, L.S. (2021). Pangan Fungsional Berbasis Susu dan Produk Turunannya. Journal of Surimi (Sustainable Research In Management of Agroindustry). 1 (1), 13-19. https://doi.org/10.35970/surimi.v1i1.535

Sudarwati, W., \& Prasetyawati, M. (2016). Evaluasi Pengembangan Industri Kreatif Pemula dalam Upaya Meningkatkan Daya Saing. Prosiding Seminar Nasional Sains dan Teknologi, Fakultas Teknik Universitas Muhammadiyah Jakarta, 8 November 2016

Suriasih. (2013). Kefir susu sapi Bali meningkatkan kadar IgG, IgA, dan sel penghasil IgA pada saluran pencernaan dan serum mencit BALB/C yang diinfeksi dengan Escherichia coli. Disertasi Program Pasca Sarjana Universitas Udayana. Denpasar. 